\title{
The parliamentary scene
}

\section{Abortion (Amendment) Bill}

Yet again this autumn MPs will be talking about abortion, for $\mathrm{Mr}$ John Corrie's amendment Bill has now reached its committee stage, having been given a majority of 144 on its second reading on I3 July.

Despite a passage of 12 years since it came into force, Britain's Abortion Act still arouses deeplyfelt criticism in several quarters. The Corrie Bill, like its predecessors, is intended to appease these critics by 'tightening up' the law. In presenting his Bill to the House of Commons $\mathrm{Mr}$ Corrie argued that it had never been Parliament's intention to allow abortion on request - but that that was exactly what had happened.

The Bill's provisions cover three main areas. Firstly, the wording of the clause defining the grounds on which termination of pregnancy would be lawful would be altered from 'a risk' to the health of the woman to 'a grave risk'. Secondly, the upper limit of gestation at which termination would be lawful would be lowered from 28 to 20 weeks; and, thirdly, the Bill would set up a scheme for licensing the pregnancy advisory services.

A total of 162 Conservative and 68 Labour MPs voted for the Bill, reflecting the wide support within the House for some revision of the law. Many seemed to have been swayed by the publicity given to several recent cases in which late in pregnancy aborted fetuses had survived the termination procedure. Dr Gerard Vaughan, a former consultant child psychiatrist who is now Minister of Health, told MPs that the public had been horrified by reports (which he believed were not correct) that on occasions these fetuses had been capable of independent life. In these circumstances the fetus might cry and indeed possibly remain alive for several hours, but prolonged survival was most unlikely. Nevertheless, he thought that the length of gestation at which abortion should be legal should be reduced from 28 to 24 weeks.

$\mathrm{Mr}$ Corrie assured the House that he would be prepared to look at amendments during the committee stage to change the limit in his Bill from 20 to 24 weeks; but there is a specific exception in the Bill so that this limit time does not apply if the baby is known, or reasonably expected, to be severely handicapped. And since terminations after $\vec{\circ}$ 20 weeks (which account for about I per cent of $\overrightarrow{\vec{\omega}}$ the total) are done mostly because of congenital $\stackrel{\circ}{\circ}$ handicap, the Bill would not reduce their numbers $\overline{\bar{z}}$ substantially.

Why, however, if MPs are so concerned, are all the medical organisations - including the Royal i College of Obstetricians and Gynaecologists and the $\bullet$ British Medical Association - united in opposition $\frac{5}{3}$ to this proposed new legislation? Essentially, the objection comes from the doctors whose daily work means their having to take decisions about the $\overparen{\varnothing}$ termination of pregnancy. Almost all the evidence $\stackrel{3}{\square}$ given by doctors to Mrs Justice Lane's committee $\stackrel{\Phi}{\stackrel{\Phi}{~}}$ of inquiry into the working of the Act was on the $\vec{\varphi}$ same lines: the Act was, said obstetricians, working well - wherever adequate facilities were provided. Even so, the decision to terminate a pregnancy is 0 rarely easy either for the mother or the doctor concerned, and this is especially so late in pregnancy. On principle, most doctors believe that legislation $\frac{\otimes}{\circ}$ should not be so specific that it has to be taken into $\propto$ account while making clinical decisions. Clinical $\overrightarrow{\vec{O}}$ judgment should, they argue, be concerned only $\exists$ with what is best for the patient - not what is or is not possible within the law. Doctors are, too, very much aware that no matter how the law is changed there will always be a few practitioners prepared to $\Phi$ bend the regulations to conform with their own views $\frac{5}{3}$ on the indications for termination of pregnancy. Legislation is a poor way of changing behaviour in $ᄋ$ this sort of area. Finally, the pace of technological change in medicine is nowadays so fast that any $\mathrm{S}$ restrictions or requirements specified by legislation $D$ may be outdated soon after the Act reaches the Statute Book.

Perhaps before they vote again on this Bill MPs should look at experience in other countries, some $N$ with more restrictive abortion legislation and some $\omega$ with more permissive laws. In general, what seems? to determine the true abortion rate (legal and illega ${ }^{\circ}$ abortions) is not the law but the socio-economic $\mathbb{D}_{\text {D }}$ circumstances of the population and the availability of contraception; and what determines the proportion of terminations late in pregnancy is the height of the financial and administrative barriers to $\frac{?}{\mathbb{Q}}$ abortion. 